S. Venediktov, Dr of Law, Prof.

Taras Shevchenko National University of Kyiv, Kyiv, Ukraine

\title{
TOWARDS THE ISSUE ON THE DENUNCIATION OF THE CONVENTIONS OF THE INTERNATIONAL LABOUR ORGANIZATION
}

The article analyzes the legal regulation for the denunciation of the conventions of the International Labour Organization. Both automatic and The article analyzes the legal regulation for the
"pure" denunciations of conventions are examined.

Ratified ILO conventions have traditionally been one of the key sources of national labour law. However, over time, some of them have lost their relevance and practical importance. The most common way to waive obligations under ratified conventions is to denounce them. Denunciation is provided for in every ILO convention, with the exception of Conventions Nos. 80 and 116, which contain rules relating to the partial revision of previous conventions. In addition, a mechanism for partial denunciation is provided for certain conventions. Such a mechanism is expressed in the possibility of denunciation of: a) certain sections of the Convention, e.g. Invalidity, Old-Age and Survivors' Benefits Convention, 1967 (No. 128); b) certain categories covered by the scope of the convention, e.g. Working Environment (Air Pollution, Noise and Vibration) Convention, 1977 (No. 148).

It is determined that most denunciations of ILO conventions occur automatically, due to the country's ratification of more recent conventions. In Ukraine, all denunciation of ILO conventions took place automatically. The "pure" denunciations are more relevant to outdated conventions or conventions that no longer correspond to existing fundamental principles in the world of work. An example is Night Work (Women) Convention (Revised), 1948 (No. 89), which was denounced by Austria, Greece, Italy, Ireland, France, the Czech Republic, etc. The provisions of this Convention are no longer in line with the ILO's existing policy of equal rights and opportunities for men and women in world of work. The practice of denouncing up-to-date ILO conventions should not be called widespread, primarily due to the need for mandatory prior tripartite consultations on this issue, which involves comprehensive consideration of the interests of government, employees and employers.

Ratification by the country of the ILO conventions puts national labour legislation in a fairly clear framework, which in some cases may serve as a reason for slowing down specific areas of its further development. After all, certain conventions were adopted at a time when completely different regulatory approaches in the world of work were applied than those that exist today. Resolving this issue is possible through the timely and balanced application of the denunciation procedure. This procedure, provided for in almost all ILO conventions, should be considered as a clear example of the harmonious evolution of international labour standards.

Keywords: International Labour Organization, conventions, automatic denunciation, "pure" denunciation, ratification, national legislation.

Bulletin of Taras Shevchenko National University of Kyiv.

Legal Studies, 2021; 2 (117): 18-24

удК: 341.9

DOI: https:doi.org/10.17721/1728-2195/2021/2.117-4
ISSN 1728-2195

C) Taras Shevchenko National University of Kyiv,

Publishing center "Kyiv University", 2021

I. Діковська, д-р юрид. наук, профь. ORCID ID: 0000-0002-0728-3934

Київський національний університет імені Тараса Шевченка, Київ, Україна

\section{СИНХРОНІЗАЦІЯ ЗАСТОСОВУВАНОГО ПРАВА ТА МІЖНАРОДНОЇ ЮРИСДИКЦІЇ У СПАДКОВИХ СПРАВАХ І СПРАВАХ ЩОДО МАЙНОВИХ ВІДНОСИН ПОДРУЖЖЯ В ЄС TA УКРAÏHı}

Метою цієї статті є визначення способів синхронізації між застосовуваним правом і міжнародною юрисдикцією у спадкових справах і справах, що стосуються майнових відносин подружжя, в окремих регламентах ЄС і нормах, які можуть визначати міжнародну юрисдикцію та застосовуване право в Україні, а також відповідь на питання про те, чи відповідають норми Закону України "Про міжнародне приватне право", що забезпечують синхронізацію між застосовуваним правом та юрисдикцією у спадкових справах і справах щодо майнових відносин подружжя, потребам правового регулювання приватних відносин.

Використання порівняльного, діалектичного, формально-логічного методів дозволило дійти висновку про те, що синхронізачія між юрисдикцію та застосовуваним правом забезпечується шляхом використання однакових критеріїв для визначення міжнародної юрисдикції та застосовуваного права. Норми, що забезпечують синхронізацію, можуть: 1) обов'язково призводити до застосування судом свого власного права у певних категоріях справ; 2) бути альтернативою до інших способів визначення права й юрисдикції. Визначено, що другий спосіб більше відповідає потребам правового регулювання приватних відносин, оскільки забезпечує автономію їхніх учасників.

Доведено, що норми Закону України "Про міжнародне приватне право", які визначають право, застосовуване до спадкування, а також міжнародну юрисдикцію у справах щодо цих відносин, сформульовано таким чином, що синхронізація між правом та юрисдикцією відбуватиметься лише за певних умов. Доведено, що наявність у спадковій масі нерухомого майна, розташованого за кордоном, призводитиме до застосування українським судом права іноземної держави місия розташування такого майна до питань його спадкування, навіть якщо спадкодавець - громадянин України - обрав у заповіті право України, як право, застосовуване до спадкування. Зроблено висновок про необхідність удосконалення Закону України "Про міжнародне приватне право" таким чином, щоб вибір спадкодавцем права Украӥни у заповіті як права, застосовуваного до спадкування, стосувався як рухомого, так і нерухомого майна, незалежно від його розташування.

Ключові слова: синхронізація між юрисдикцією і застосовуваним правом; право, що застосовується до спадкування; міжнародна юрисдикція у спадкових справах; міжнародна юрисдикція у сімейних справах; Спадковий регламент; Регламент щодо режимів подружньої власності; Договір між Україною і Республікою Польща про правову допомогу та правові відносини у цивільних і кримінальних справах; Закон України "Про міжнародне приватне право".

ВстУп. Як відомо, предметом регулювання міжнародного приватного права є приватні відносини з іноземним елементом. Його наявність призводить до того, що у певних випадках правозастосовчий орган використовує до них право іноземної держави. Можливість застосовування права іноземної держави є ознакою толерантності того правопорядку, який це дозволяє; а також свідчить про прогрес людської цивілізації [1, с. 96]. Разом із тим, загальновизнаною $є$ складність застосовування норм іноземного права, причому вона існує неза- лежно від того, на кого (на суд чи на сторони) покладається встановлення змісту іноземного права [1, с. 91], а також, не зважаючи на наявність міжнародних договорів, які надають можливість отримувати інформацію про зміст іноземного права. Зазначимо, що в ідеалі суддя має застосовувати іноземне право так, як його би застосовував суддя, для якого це право не $є$ іноземним, тобто, як фрахівець, вихований у відповідній правовій традиції. Звісно, часто для цього недостатньо лише мати інфрормацію про зміст іноземного права. Особливо 
це стосується спадкового та сімейного права, принципи і норми яких суттєво відрізняються у різних правових системах, що пов'язано з тим, що вони беруть свої витоки з релігійних уявлень і національних звичаїв. Нерозуміння іноземного права, принципів його тлумачення часто призводить до його неправильного застосовування. Синхронізація між міжнародною юрисдикцією та застосовуваним правом, яка призводить до застосування судом його власного права у справах з іноземним елементом, є одним зі способів подолання цієї проблеми.

Право, що застосовують до спадкових відносин 3 іноземним елементом і майнових відносин подружжя, було предметом дослідження окремих українських правознавців: В. І. Кисіля [2, с. 342-378], О. О. Кармази [3], О. О. Бичківського [4], Г. О. Галущенко [5, с. 117-135], М. О. Михайлів [6], Є. Є. Фурси [7]. Міжнародній юрисдикції у спадкових і сімейних справах приділяли увагу Г. А. Цірат $[8$, с. 215-313] та Ю. В. Черняк [9, с. 151261]. Проте синхронізація між міжнародною юрисдикцією та застосовуваним правом в українській юридичній науці не досліджувалася.

3 огляду на це, метою цієї статті є визначення способів синхронізації між міжнародною юрисдикцією та застосовуваним правом у спадкових справах і справах, що стосуються майнових відносин подружжя, в окремих регламентах $€ C$ і нормах, які можуть визначати міжнародну юрисдикцію та застосовуване право в Україні, а також відповідь на питання про те, чи відповідають норми Закону України "Про міжнародне приватне право" від 23 червня 2005 р. № 2709 [10] (далі - ЗУ "Про МПрП"), які забезпечують синхронізацію між застосовуваним правом та юрисдикцією у спадкових справах і справах щодо майнових відносин подружжя, потребам правового регулювання приватних відносин.

Об'єктом дослідження стали окремі норми, які визначають міжнародну юрисдикцію та застосовуване право Регламенту (ЄС) № 650/2012 Європейського парламенту та Ради від 4 липня 2012 р. щодо юрисдикції, застосовуваного права, визнання й виконання рішень i прийняття та виконання аутентичних інструментів у спадкових справах, а також норми про створення Європейського спадкового сертифіката [11] (далі - Спадковий регламент); Регламенту Ради (ЄС) N 2016/1103 від 24 червня 2016 р. щодо здійснення розширеного співробітництва у сфрері юрисдикції, застосовуваного права, визнання та виконання рішень у справах щодо режимів подружньої власності (далі - Регламент щодо режимів подружньої власності) [12]; Договору між Україною і Республікою Польща про правову допомогу та правові відносини у цивільних і кримінальних справах від 24 травня 1993 р. [13] (далі - Договір із Польщею або Договір), як прикладу договору про правову допомогу, який визначає міжнародну юрисдикцію та застосовуване право, а також ЗУ "Про МПрП". (У цій статті терміном "міжнародна юрисдикція" або "компетенція" (у випадку аналізу норм Договору з Польщею) позначають повноваження судів розглядати і вирішувати справи, які стосуються приватних відносин 3 іноземним елементом. Також у ній вживатиметься термін "підсудність" для характеристики справи, оскільки ЗУ "Про МПрП" не вживає термін "юрисдикція", а використовує термін "підсудність"; тобто, у цій статті: суд має юрисдикцію (компетенцію), а справа є підсудною.

Методологія дослідження. Для досягнення мети дослідження використано такі методи наукового пізнання: порівняльний, діалектичний, формально-логічний. Зокрема, порівняльний метод використовувався для знаходження спільних і відмінних рис у способах забезпечення синхронізації між юрисдикцією та застосовува- ним правом у спадкових справах і справах щодо майнових відносин подружжя згідно зі Спадковим регламентом, Регламентом щодо режимів подружньої власності, Договором із Польщею та ЗУ "Про МПрП". Діалектичний метод використовувався для з'ясування того, наскільки способи синхронізації між юрисдикцією та застосовуваним правом відповідають потребам правового регулювання приватних відносин з іноземним елементом, зокрема, наскільки вони забезпечують свободу учасників таких відносин вирішувати, чи потрібна така синхронізація. Формально-логічний метод дозволив виокремити способи синхронізації між юрисдикцією та застосовуваним правом.

\section{ВИКЛАД ОСНОВНОГО МАТЕРІАЛУ}

Спадковий регламент [11]. 317 серпня 2015 р. у більшості країн ЄС визначення міжнародної юрисдикції у спадкових справах, права, що застосовується у спадкових відносинах з іноземним елементом, регулюється Спадковим регламентом, який називають одним із найважливіших результатів, досягнутих у сфері кодифікації міжнародного приватного права [14, с. 1]. Спадковий регламент іменують "найбільш амбітним і всеосяжним проєктом щодо заходів, спрямованих на забезпечення синхронності норм, що застосовуються у державах для визначення застосовуваного права та юрисдикції" [15, с. 133]. Ця синхронність досягається через механізми, які спрямовані на те, щоб суд застосовував своє власне право, розглядаючи спадкову справу з іноземним елементом, що має на меті полегшення спадкового процесу для зацікавлених сторін і суду.

По-перше, синхронізація між юрисдикцією за застосовуваним правом забезпечується статтями, які містять загальні правила визначення юрисдикції та загальне правило визначення застосовуваного права. Так, ст. 4 Спадкового регламенту, яка має назву "Загальна юрисдикція" встановлює таке правило: "Суди державичлена, у якій спадкодавець мав звичайне місце проживання у момент смерті, мають юрисдикцію виносити рішення щодо спадкування в цілому". У свою чергу відповідно до ст. 21 (1) Спадкового регламенту: "1. Якщо інше не передбачено цим Регламентом, право, застосовуване до спадкування в цілому, є правом держави, у якій спадкодавець мав своє звичайне місце проживання у момент смерті". Тобто, критерій "звичайного місця проживання спадкодавця у момент смерті" виконує подвійну функцію: використовується і для визначення юрисдикції (ст. 4), і для визначення застосовуваного до спадкування права (ст. 21), які в обох статтях повинні тлумачитися однаково для забезпечення синхронізації між юрисдикцією і правом [16, с. 65].

Зазначимо, що в окремих випадках Спадковий регламент, як виняток, допускає застосування до спадкування не права держави звичайного місця проживання спадкодавця у момент смерті, а права держави, з якою спадкодавець був тісніше пов'язаний. Зокрема, відповідно до ст. 21 (2) Спадкового регламенту, "якщо, як виняток, з усіх обставин справи зрозуміло, що на момент смерті спадкодавець явно був більш тісно пов'язаний із Державою іншою, ніж Держава, чиє право застосовувалося б відповідно до § 1, правом, застосовуваним до спадкування буде право цієї держави". Проте коментатори йменують цю норму "дивною" [17, с. 317] i зазначають, що навряд чи вона застосовуватиметься. Адже держава, з якою спадкодавець мав найбільш тісний зв'язок, $є$, по суті, державою зосередження його життєво важливих інтересів. Проте у розумінні Спадкового регламенту, місце життєво важливих інтересів $€$ місцем звичайного проживання спадкодавця [17, с. 317]. А в 
силу ст. 21 (2) Спадкового регламенту право держави, 3 якою спадкодавець найбільш тісно пов'язаний, застосовується в результаті відмови від застосування колізійної прив'язки "звичайне місце проживання спадкодавця у момент смерті".

По-друге, синхронізація між юрисдикцією за застосовуваним правом забезпечується статтями, що встановлюють можливість укладення угоди про вибір суду чи судів певної держави-члена, а також можливість вибору права, застосовуваного до спадкування. Так, відповідно до ст. 5 (1) Спадкового регламенту "у випадках, якщо право, обране спадкодавцем для регулювання спадкування відповідно до ст. $22 €$ правом державичлена, зацікавлені сторони можуть домовитися, що суд чи суди цієї держави-члена мають виключну юрисдикцію винести рішення стосовно будь-якого питання щодо спадкування". Відповідно до ст. 22 (1) Спадкового регламенту особа може обрати право держави, громадянство якої вона має на момент вибору чи на момент смерті, для регулювання спадкування в цілому. Якщо особа має декілька громадянств, вона може обрати право будь-якої з держав, чиїм громадянством вона володіє на момент вибору або на момент смерті. Пункт 38 Спадкового регламенту пояснює обмеження можливості вибору права лише правом держави громадянства спадкодавця необхідністю забезпечення зв'язку між спадкодавцем і застосовуваним правом, а також потребою уникнення ситуацій, коли право обирається з метою обману законних очікувань осіб, які мають право на обов'язкову частку у спадщині.

Необхідність включення норми, яка дозволяє вибір права, застосовуваного до спадкування в цілому, пояснюється тим, що спадкодавець на момент планування своєї спадщини може мати сумніви щодо свого останнього місця проживання перед смертю, а, відтак, і права, що буде застосовуватися до спадкування, або має бажання уникнути складнощів, пов'язаних із визначенням останнього місця проживання з урахуванням усіх обставин конкретної справи [18, с. 126].

Тобто, норми ст. 5 (1) та 22 (1) Спадкового регламенту дозволяють зацікавленим сторонам у випадку, якщо спадкодавець обрав застосовуване до спадкування право однієї з держав-членів ЄС, укласти угоду про вибір суду на користь судів чи суду держави-члена, громадянства спадкодавця, і, таким чином, синхронізувати юрисдикцію та застосовуване право.

По-третє, синхронізація між юрисдикцією та застосовуваним правом у певних випадках буде можливою навіть тоді, коли юрисдикція визначатиметься за субсидіарними правилами ст. 10 Спадкового регламенту. Зокрема, вона встановлює таке: "1. Якщо місце проживання спадкодавця у момент смерті розташоване не у державі-члені, суди держави-члена, у якій розташоване спадкове майно, тим не менше матимуть юрисдикцію виносити рішення щодо спадкування в цілому, якщо: (а) спадкодавець мав громадянство цієї держави-члена у момент смерті; або за відсутності такого (b) спадкодавець мав попереднє звичайне місце проживання у цій державі-члені за умови, що на момент звернення до суду минуло не більше п'яти років відтоді, коли місце звичайного проживання змінилося. 2. Якщо суд держави-члена не має юрисдикції відповідно до § 1 , суди держави-члена, у якій розташоване спадкове майно, тим не менше мають юрисдикцію виносити рішення щодо цього майна".

Юрисдикція, передбачена ст. 10 Спадкового регламенту, іменується "субсидіарною", тому що норми цієї статті встановлюють юрисдикцію судів держави-члена за відсутності підстави для застосування правила про загальну юрисдикцію, передбаченого ст. 4 Спадкового регламенту [19, с. 136].

Умовами виникнення субсидіарної юрисдикції є: відсутність звичайного місця проживання спадкодавця у державі-члені у момент смерті; перебування хоча б якоїсь частини спадкового майна на території державичлена [19, с. 136]. Причому зі змісту ст. 10 Спадкового регламенту коментатори роблять справедливий висновок про те, що вона не вимагає, щоб усе спадкове майно чи основна його частина, чи частина, яка не є незначною, знаходилися у державі-члені. Тобто, для виникнення субсидіарної юрисдикції достатньо, щоб будьяка, навіть незначна, частина спадкового майна перебувала у державі-члені.

Установлення юрисдикції на підставі ст. 10 Спадкового регламенту означає, що суд, який розглядає справу, не $є$ судом держави місця звичайного проживання спадкодавця у момент смерті. Враховуючи те, що відповідно до ст. 21 (1) Спадкового регламенту основною колізійною прив'язкою для визначення права застосовуваного до спадкування є право держави, у якій спадкодавець мав своє звичайне місце проживання у момент смерті, субсидіарна юрисдикція, яка встановлюється відповідно до ст. 10 Спадкового регламенту, у багатьох випадках буде призводити до того, що суд, який розглядатиме справу, застосовуватиме не власне право, а право іншої держави, хоча п. 27 Преамбули Спадкового регламенту чітко вказує на те, що у більшості випадків Регламент має на меті забезпечити застосування відповідними органами свого власного права. Коментатори звертають увагу, що у разі субсидіарної юрисдикції це можливо за двох умов: 1) якщо суд держави-члена отримує юрисдикцію, як суд держави, громадянство якої мав спадкодавець у момент смерті та в якій розташоване спадкове майно (ст. 10 (1) (а); та 2) право держави громадянства спадкодавця застосовують за правилами зворотного відсилання відповідно до ст. 34 (1) (а) Спадкового регламенту [20, с. 147], згідно з якою "застосування права будь-якої третьої держави означає застосування ії чинних норм права, включаючи норми міжнародного приватного права, якщо вони містять відсилання до права держави-члена".

Регламент щодо режимів подружньої власності [12]. На відміну від Спадкового регламенту, синхронізація між юрисдикцією та застосовуваним правом не була однією 3 ключових цілей створення Регламенту щодо режимів подружньої власності. Відтак, визначення застосовуваного права і юрисдикції на підставі його норм часто може призводити до застосування іноземного права судом певної держави-члена. Так, наприклад, застосування ст. 6 (a) цього Регламенту для визначення юрисдикції і ст. 26 (1) - для визначення застосовуваного права призведе до того, що справу щодо режиму подружньої власності розглядатиме суд держави-члена, на чиїй території подружжя звичайно проживало у момент звернення до суду; при цьому він буде застосовувати право держави першого звичайного місця проживання подружжя після укладення шлюбу, яке, звісно, може не збігатися з місцем їхнього звичайного проживання у подальшому, зокрема, у момент звернення до суду.

Разом із тим, ст. 7 Регламенту створює можливість однозначної синхронізації між правом і юрисдикцією шляхом надання подружжю права укладати угоду про вибір судів держави, право якої вони обрали для регулювання своїх відносин. Зокрема, ст. 7 Регламенту щодо режимів подружньої власності передбачає, що у певних випадках (а саме, якщо юрисдикція не буде визначатися на підставі інших регламентів, наприклад, Спадкового, коли питання щодо режиму подружньої власно- 
сті розглядається у контексті спадкової справи) сторони можуть домовитися, що суди держави-члена, чиє право застосовується відповідно до ст. 22 чи п. (а) або (b) ст. 26 (1) цього Регламенту, матимуть виключну юрисдикцію виносити рішення у справах щодо режимів подружньої власності. (Відповідно до ст. 22 (1) Регламенту щодо режимів подружньої власності подружжя чи майбутнє подружжя може домовитися про визначення чи зміну права, застосовуваного до їхнього режиму подружньої власності, за умови, цим правом $є$ одне з таких: (а) право держави, у якій подружжя чи майбутнє подружжя, чи один із них звичайно проживає на момент укладення угоди; чи (b) право держави громадянства будь-кого з подружжя або з майбутнього подружжя. За відсутності вибору права, здійсненого відповідно до ст. 22, правом, що застосовується до режиму подружньої власності є право держави: (а) першого звичайного місця проживання подружжя після укладення шлюбу; або, за відсутності такого (b) спільного громадянства подружжя на момент укладення шлюбу).

Як пояснюють розробники цього Регламенту, така можливість була надана "для збільшення передбачуваності і свободи подружжя" [21]. Пункт 36 Преамбули цього Регламенту серед причин надання сторонам такої можливості згадує ще "збільшення правової визначеності" [12], яке, безумовно, виникає, якщо подружжя обирає суди держави, право якої застосовується до регулювання їхнього режиму подружньої власності.

Юрисдикція і право у нормах України. В Україні норми, які визначають міжнародну юрисдикцію, а також застосовуване право у спадкових справах і справах щодо майнових відносин подружжя, містяться в окремих договорах про правову допомогу та ЗУ "Про МПрП" [10]. Причому в силу пріоритету норм міжнародних договорів над актами законодавства України, передбаченого ст. 19 (2) ЗУ "Про міжнародні договори України" [22], а також ст. 3 ЗУ "Про МПрП", норми останнього застосовують лише у тому випадку, коли міжнародна юрисдикція і застосовуване право у певних справах не визначаються міжнародним договором України.

Договір із Польщею. У цілому, зазначимо, що у договорах про правову допомогу діє принцип синхронізації міжнародної юрисдикції та застосовуваного права у спадкових справах та у справах щодо майнових відносин подружжя, хоча сам підхід до визначення права, що застосовується до спадкування та майнових відносин подружжя, а також міжнародної юрисдикції у цих правах, не $€$ тотожним Спадковому регламенту чи Регламенту щодо режимів подружньої власності. Так, наприклад, ст. 37 (1) Договору з Польщею передбачає таке: "Правові відносини в галузі успадкування рухомого майна регулюються законодавством тієї Договірної Сторони, громадянином якої був заповідач у момент смерті" (у тексті польською мовою не "заповідач", а "спадкодавець" [23]). У свою чергу, "спадкові справи щодо рухомого майна належать до компетенції відповідних органів тієї Договірної Сторони, громадянином якої був заповідач у момент смерті" (у тексті польською мовою - "спадкодавець") за ст. 41 (1) Договору [23]. Спадкування нерухомого майна регулюють за правом Договірної Сторони, у якій воно розташоване (ст. 37 (2) Договору). Компетенція у спадкових справах щодо нерухомого майна належить відповідним органам Договірної Сторони, на території якої майно розміщено (ст. 41 (2) Договору).

Стаття 25 Договору дає підстави для висновку, що міжнародна юрисдикція та право, застосовуване до майнових відносин подружжя, також синхронізовані. Так, у силу ст. 25 (1) Договору "майнові відносини по- дружжя визначаються законодавством тієї Договірної Сторони, громадянами якої $є$ подружжя в час подання клопотання". Розглядати таку справу $є$ компетентним суд тієї Договірної Сторони, громадянами якої було подружжя в час подання заяви (ст. 25 (3) Договору). Інші частини ст. 25 Договору синхронізують застосовуване право та юрисдикцію у випадках, коли один із подружжя має громадянство однієї Сторони, а інший - іншої Договірної Сторони (див. ст. 25 (2) та ст. 25 (4) Договору відповідно); а також у випадках, коли справа стосується майнових відносин подружжя щодо нерухомого майна (ст. 25 (5) Договору).

зу "Про МПрП". З аналізу ст. 70, 71 ЗУ "Про МПрП" випливає, що правом, яке застосовується до спадкування рухомого майна, яке не підлягає державній реєстрації в Україні, може бути: 1) право держави, у якій спадкодавець мав останнє місце проживання; 2) право держави громадянства спадкодавця, якщо воно обрано ним у заповіті. Зауважимо, що "вибір права спадкодавцем буде недійсним, якщо після складання заповіту його громадянство змінилося" (ст. 70 ЗУ "Про МПрП").

Право, що застосовується до спадкування нерухомого майна згідно зі ст. 71 ЗУ "Про МПрП" визначають як право держави, на території якої міститься нерухоме майно. Таким чином, на відміну від Спадкового регламенту ЗУ "Про МПрП" використовує дуалістичний підхід до визначення права, застосовуваного до спадкових відносин, тобто, використовує різні колізійні прив'язки до спадкування рухомого та нерухомого майна. У багатьох випадках це призводить до того, що спадкування рухомого та нерухомого майна регулюється правом різних держав. Крім того, у силу другого речення ст. 71 ЗУ "Про МПрП", спадкування майна, яке підлягає державній реєстрації в Україні, завжди регулюється правом України.

Причому, "якщо нерухоме майно, щодо якого виник спір, міститься на території України", а також "якщо у справі про спадщину спадкодавець - громадянин України і мав у ній місце проживання", то підсудність судам України є виключною (ст. 77 (ч. 1, п. 1, 3) ЗУ "Про МПрП"). Крім того, спадкова права з іноземним елементом може бути підсудною судам України, якщо сторони цієї справи уклали угоду про це (ст. 76 (ч. 1, п. 1) ЗУ "Про МПрП") або "якщо на території України відповідач у справі має місце проживання або місцезнаходження, або рухоме чи нерухоме майно" (ст. 76 (ч. 1, п. 2) ЗУ "Про МПрП").

Тобто, в окремих випадках застосовуване право та міжнародна юрисдикція у спадкових справах згідно 3 ЗУ "Про МПрП" синхронізовані, в інших - ні. Так, скажімо, якщо до спадкової маси входить нерухоме майно, яке розташоване як в Україні, так і за кордоном, i спадкодавець мав останнє місце проживання за кордоном, то український суд, який розглядає спадкову справу чи то в силу положень ст. 77 , чи ст. 76 ЗУ "Про МПрП", буде застосовувати своє власне право лише щодо спадкового нерухомого майна, розташованого в Україні; стосовно спадкування нерухомого майна, розташованого за кордоном, та рухомого майна, що не підлягає державній реєстрації в Україні, він повинен буде застосовувати іноземне право.

Стосовно майнових відносин подружжя слід зауважити таке. У силу ст. 61 (1) ЗУ "Про МПрП" подружжя може обирати право, що регулює його майнові відносини з-поміж: 1) права особистого закону одного з подружжя; або 2) права держави, в якій один із них має звичайне місце перебування; або 3) стосовно до нерухомого майна, - права держави, в якій це майно розміщено; з можливістю його подальшої зміни у разі зміни особистого закону або звичайного місця перебу- 
вання того з подружжя, до особистого закону або звичайного місця перебування якого було прив'язане обране право (ст. 61 (2) ЗУ "Про МПрП"). За відсутності обраного права майнові відносини подружжя регулюються правом, визначеним на підставі колізійних норм ст. 60 ЗУ "Про МПрП".

ЗУ "Про МПрП" не містить спеціальних норм для визначення юрисдикції у справах з іноземним елементом щодо майнових відносин подружжя. Це означає, що юрисдикція українського суду у таких справах може виникати: 1) на підставі норм про виключну підсудність справ, зокрема, це буде у разі виникнення спору щодо нерухомого майна, розташованого на території України, що є об'єктом майнових прав подружжя (ст. 77 (ч. 1, п. 2) ЗУ "Про МПрП"); 2) на підставі ст. 76 зУ "Про МПрП", наприклад, якщо на території України відповідач у справі має місце проживання або рухоме чи нерухоме майно, на яке можна накласти стягнення (ст. 76 (ч. 1, п. 2) ЗУ "Про МПрП"), або якщо подружжя уклало угоду про підсудність справи судам України (ст. 76 (ч. 1, п. 1) ЗУ "Про МПрП").

Тобто, якщо юрисдикція і застосовуване право у справах щодо майнових відносин подружжя будуть визначатися на підставі ЗУ "Про МПрП", вони будуть синхронізовані, якщо: 1) подружжя, яке не має спільного особистого закону, обрало для регулювання своїх майнових відносин право України (це можливо, у випадках: право України є особистим законом когось із них; - Україна $€$ звичайним місцем перебування когось із них; якщо вибір права стосується майнових відносин щодо нерухомості, розташованої в Україні), або за відсутності такого вибору, - право України є спільним особистим законом подружжя або, якщо подружжя не має спільного особистого закону, - Україна є їхнім останнім спільним місцем проживання, за умови, що хоча б один із них усе ще має місце проживання у ній, або, якщо обидва з подружжя мають найбільш тісний зв'язок з Україною іншим чином) й уклало угоду про підсудність справи судам України; 2) якщо спір стосується виключно нерухомого майна подружжя, розташованого в Україні, i вони обрали для регулювання своїх майнових відносин щодо цього майна право України, а юрисдикція на вирішення спору судами України визначається на підставі норми про виключну підсудність ст. 77 (ч. 1, п. 1) ЗУ "Про МПрП"; 3) якщо право України застосовується до майнових відносин подружжя в силу здійсненого ними вибору чи на підставі застосування ст. 60 ЗУ "Про МПрП", а суди України мають юрисдикцію вирішувати справу, оскільки відповідач має місце проживання, рухоме чи нерухоме майно в Україні.

ВИСнОВКИ. Синхронізація між юрисдикцію та застосовуваним правом забезпечується шляхом використання однакових критеріїв для визначення міжнародної юрисдикції та застосовуваного права (наприклад, "останнього звичайного місця проживання спадкодавця" у Спадковому регламенті чи "місця розташування нерухомого майна" у Договорі з Польщею чи ЗУ "Про МПрП"). За способом формулювання норми, які забезпечують синхронізацію, можуть: 1) обов'язково призводити до застосування судом свого власного права у певних категоріях справ (наприклад, згідно з Договором із Польщею відносини щодо спадкування рухомого майна можуть регулюватися лише правом держави громадянства спадкодавця, і лише суд цієї держави має юрисдикцію розглядати справи щодо такого спадкування); 2) бути альтернативою до інших способів визначення права й юрисдикції, яка використовується, якщо сторони відповідного правовідношення укладають угоди про вибір права і вибір судів, прив'язуючись у них до права і судів однієї і тієї самої держави (як, наприклад, у Регламенті щодо режимів подружньої власності). В особливий спосіб можливість такої альтернативи сформульовано у Спадковому регламенті: спочатку спадкодавець обирає застосовуване до спадкування право у розпорядженні на випадок смерті; потім, якщо спадкоємці мають намір обрати юрисдикцію судів (суду) держави, право якої застосовується до спадкування в силу вибору, здійсненого спадкодавцем, вони укладають угоду про вибір судів чи суду такої держави. На наш погляд, формулювання норм про міжнародну юрисдикцію і застосовуване право, які забезпечують синхронізацію між правом і юрисдикцією як альтернативу іншим способам визначення застосовуваного права і юрисдикції, що може використовуватися за бажанням сторін відповідного правовідношення, більше відповідає потребам правового регулювання приватних відносин, учасники яких, як відомо, наділяються автономією, яка має виражатися і в їхній можливості самостійно визначати, чи потрібна синхронізація між правом і юрисдикцією для регулювання їхніх відносин.

Норми ЗУ "Про МПрП", що визначають право, застосовуване до майнових відносин подружжя, а також норми, які можуть визначати юрисдикцію у справах щодо таких відносин, створюють можливість і для застосування іноземного права судом України, і для застосування ним права України. Синхронізація між застосовуваним правом і юрисдикцією відбувається, якщо подружжя уклало угоди про вибір права і судів України, а також у деяких інших випадках.

Норми ЗУ "Про МПрП", які визначають право, застосовуване до спадкування, а також міжнародну юрисдикцію у справах щодо цих відносин, сфрормульовано таким чином, що синхронізація між правом та юрисдикцією відбуватиметься лише за певних умов. Наявність у спадковій масі нерухомого майна, розташованого за кордоном, призводитиме до застосування українським судом права іноземної держави місця розташування такого майна до питань спадкування, навіть якщо спадкодавець - громадянин України - обрав у заповіті право України, як право застосовуване до спадкування. Тобто, слід констатувати, що повна синхронізація між юрисдикцією і застосовуваним правом неможлива доки зУ "Про МПрП" використовує дуалістичний підхід до визначення застосовуваного права, навіть якщо цього бажають учасники спадкових правовідносин. Відсутність можливості повної синхронізації між застосовуваним правом і юрисдикцією не полегшує регулювання спадкових відносин з іноземним елементом. Тому, на наш погляд, ЗУ "Про МПрП" має бути удосконалений таким чином, щоб вибір спадкодавцем права України у заповіті як права, застосовуваного до спадкування, стосувався як рухомого так і нерухомого майна, незалежно від того, де воно розташоване. Це дозволить синхронізувати застосовуване право і юрисдикцію.

Водночас зазначимо, що для вдосконалення механізму синхронізації міжнародної юрисдикції і застосовуваного права у ЗУ "Про МПрП" недостатньо змінювати лише норми, що визначають право, застосовуване до спадкових відносин. Норми, які визначають юрисдикцію у спадкових справах, також потребують удосконалення, зокрема, з урахуванням досвіду Спадкового регламенту, що може стати предметом подальших наукових досліджень. 


\section{Список використаних джерел}

1. Basedow, J. The Application of Foreign Law - Comparative Remarks on the Practical Side of Private International Law/ J. Basedow// Max Planck Private Law Research Paper. - No14/17 (2014). - P. 85-97.

2. Міжнародне приватне право: підручник/ за ред. А.С. Довгерта В.І. Кисіля. - К.: Алерта, 2014. - 656 с.

3. Кармаза О.О. міжнародне спадкове право. Науково-практичний посібник/ О.О. Кармаза. - К.: Видавець Фурса С.Я.: КНТ, 2007. - 328 с.

4. Бичківський О.О. Спадкові правовідносини, ускладнені іноземним елементом: загальноправова характеристика / О. О. Бичківський // Науковий вісник Херсонського державного університету. Серія : Юридичні науки. - 2015. - Вип. 4 (1). - С. 88-92.

5. Галущенко Г.В. Питання міжнародного приватного права у міжнародних договорах України про правову допомогу/Г.В. Галущенко. К.: Юстініан, 2005. - 472 с.

6. Михайлів М.О. Особливості колізійного регулювання спадкових відносин в Україні / М. О. Михайлів // Часопис Київського університету права. - 2014. - № 3. - С. 148-152.

7. Фурса Є.Є. Вчинення консулом нотаріальних дій щодо спадкування майна: дис. ...канд. юрид. наук: 12.00.03/ Є.Є. Фурса. - К., 2015. $231 \mathrm{c}$.

8. Цірат Г.А. Міжнародний цивільний процес: сучасний стан та перспективи міжнародно-правової уніфікації. Монографія /Г.А. Цірат. - Х: Видавництво Іванченка І.С., 2013. - 482 с.

9. Черняк Ю.В. Уніфікація норм міжнародного цивільного процесу: проблемні питання теорії і судової практики вирішення сімейних спорів: дис. ...док. юрид. наук: 12.00.03/ Ю.В. Черняк. - К., 2019. - 441 с.

10. Про міжнародне приватне право: Закон України від 23 червня 2005 p. URL: https://zakon.rada.gov.ua/laws/show/2709-15 (дата звернення: 22.03.2021)

11. Regulation (EU) No 650/2012 of the European Parliament and of the Council of 4 July 2012 on jurisdiction, applicable law, recognition and enforcement of decisions and acceptance and enforcement of authentic instruments in matters of succession and on the creation of a European Certificate of Succession. Official Journal of the European Union. 2012. L 201. - P. 107-134.

12. Council Regulation (EU) 2016/1103 of 24 June 2016 implementing enhanced cooperation in the area of jurisdiction, applicable law and the recognition and enforcement of decisions in matters of matrimonial property regimes. Official Journal of the European Union. 2016 - L 183. - P. 1-29.

13. Договір між Україною і Республікою Польща про правову допомогу та правові відносини у цивільних і кримінальних справах від 24 травня 1993 року. URL: https://zakon.rada.gov.ua/laws/show/ 616 174\#Теxt (дата звернення: 22.03.2021).

14. Davi A.L. Introduction in Calvo Caravaca, A.L., Davì, A., Mansel, H.P. (eds.), The EU Succession Regulation Commentary/ A.L. Davi. Cambridge: Cambridge University Press, 2016. - P. 1-69.

15. Paulus D. Succession and Company Law in Bariatti, S., Viarengo, I., Villata, F.C. (coordinators), Towards the Entry into Force of the Succession Regulation: Building Future Uniformity upon Past Divergencies/ D. Paulus. - Milano: Università degli Studi di Milano, 2016. - P. 126-151.

16. Odersky F. Article 4: Jurisdiction in Bergquist, U.; Damascelli, D.; Frimston, R.; Lagarde, P.; Odersky, F.; Reinhartz, B. EU Regulation on Succession and Wills Commentary/ F. Odersky. - Köln: Verlag Dr. Otto Schmidt KG, 2015. - P. 64-70.

17. Calvo Caravaca A.L. Article 21, General Rule in Calvo Caravaca, A.L., Davì, A., Mansel, H.P. (eds.), The EU Succession Regulation Commentary/ A.L. Calvo Caravaca. - Cambridge: Cambridge University Press, 2016. - P. 298-322

18. Lagarde $P$. Article 22: Choice of Law in Bergquist, $U$; Damascelli, $D$; Frimston, R.; Lagarde, P.; Odersky, F.; Reinhartz, B. EU Regulation on Succession and Wills Commentary/ P. Lagarde. - Köln: Verlag Dr. Otto Schmidt KG, 2015. - P. 125-130.

19. Lein E. Artikel 10 EuErb VO in Dutta, A., Weber, J. (eds.), Internationales Erbrecht: EuErbVO, Erbrechtliche Staatsverträge, EGBGB, IntErbRVG, IntErbStR, IntSchenkungsR/ E. Lein. - München: C.H. BECK, 2016. - S. 134-141.

20. Panopoulos G. Article 10-Subsidiary jurisdiction, in Pamboukis H.P. (ed.), EU Succession Regulation No 650/2012: A Commentary/ G. Panopoulos. - Athens, München, Oxford, Baden-Baden: Nomiki Bibliothiki, C.H. BECK, Hart Publishing, Nomos, 2017. - P. 145-153.

21. European Commission. Proposal for a Council Regulation on jurisdiction, applicable law and the recognition and enforcement of decisions in matters of matrimonial property regimes COM/2016/0106 final - 2016/059, para 5.2. URL: https://eur-lex.europa.eu/legal content/en/ALL/?uri=CELEX \%3А52016РC0106 (дата звернення: 22.03.2021).

22. Про міжнародні договори України: Закон України від 29 червня 2004 p. URL: https://zakon.rada.gov.ua/laws/show/1906-15\#Text (дата звернення: 22.03.2021).

23. Umowa między Rzeczpospolitą Polską a Ukrainą o pomocy prawnej i stosunkach prawnych w sprawach cywilnych i karnych sporzadzona w Kijowie dnia 24 maja 1993 r. URL: http://isap.sejm.gov.pl/ isap.nsf/DocDetails.xsp?id=WDU19940960465 (дата звернення: 22.03.2021).

\section{References}

1. Basedow, J. (2014). The Application of Foreign Law - Comparative Remarks on the Practical Side of Private International Law. Max Planck Private Law Research Paper.14/17, 85-97 (in English)

2. Mizhnarodne pryvatne pravo: pidruchnyk/ za red. A.S. Dovgerta V.I. Kysilja [Private International Law: Handbook A.S. Dovgert and V.I. Kysil eds.] - K.: Alerta, 2014. - $656 \mathrm{~s}$ (in Ukrainian)

3. Karmaza O.O. Mizhnarodne spadkove pravo. Naukovo-praktychnyj posibnyk/ [International Succession Law: Scientific and Practical Comments]. - K.: Vydavec' Fursa S.Ja.: KNT, 2007. - 328 s (in Ukrainian)

4. Bychkivs'kyj O.O. (2015). Spadkovi pravovidnosyny, uskladneni inozemnym elementom: zagal'nopravova harakterystyka [Succession relationships with foreign element: general legal characteristics] Naukovyj visnyk Hersons'kogo derzhavnogo universytetu. Serija : Jurydychni nauky. 4 (1), 88-92 (in Ukrainian)

5. Galushhenko G.V. Pytannja mizhnarodnogo pryvatnogo prava u mizhnarodnyh dogovorah Ukrai'ny pro pravovu dopomogu [Private international law issues in the agreements of Ukraine on legal assistance] - K.: Justinian, 2005. - $472 \mathrm{~s}$ (in Ukrainian)

6. Myhajliv M.O. (2014) Osoblyvosti kolizijnogo reguljuvannja spadkovyh vidnosyn $v$ Ukrai'ni iv [Features of conflict-of-laws regulation of succession relations in Ukraine] Chasopys Kyi'vs'kogo universytetu prava. 3, 148-152 (in Ukrainian)

7. Fursa Je.Je. Vchynennja konsulom notarial'nyh dij shhodo spadkuvannja majna: dys. ...kand. juryd. nauk: [Consular notarization of succession of estate: thesis for obtaining a degree of candidate of legal sciences] K., 2015. - 231 s (in Ukrainian)

8. Cirat G.A. Mizhnarodnyj cyvil'nyj proces: suchasnyj stan ta perspektyvy mizhnarodno-pravovoi' unifikacii'. Monografija [International legal procedure: contemporary state and perspectives of international unification] $\mathrm{H}$ : Vydavnyctvo Ivanchenka I.S., 2013. - $482 \mathrm{~s}$ (in Ukrainian)

9. Chernjak Ju.V. Unifikacija norm mizhnarodnogo cyvil'nogo procesu: problemni pytannja teorii' i sudovoi' praktyky vyrishennja simejnyh sporiv: dys. ...dok. juryd. Nauk [Unification of rules of international civil procedure: problem issues of theory and case law in settlement of family matters: thesis for obtaining a degree of doctor of legal science] - K., 2019. - $441 \mathrm{~s}$ (in Ukrainian)

10. Pro mizhnarodne pryvatne pravo: Zakon Ukrai'ny vid 23 chervnja 2005 r. [Law of Ukraine on Private International Law from 23.06. 2005] URL: https://zakon.rada.gov.ua/laws/show/2709-15 (in Ukrainian)

11. Regulation (EU) No 650/2012 of the European Parliament and of the Council of 4 July 2012 on jurisdiction, applicable law, recognition and enforcement of decisions and acceptance and enforcement of authentic instruments in matters of succession and on the creation of a European Certificate of Succession. Official Journal of the European Union. 2012. L 201. - P. 107-134 (in English)

12. Council Regulation (EU) 2016/1103 of 24 June 2016 implementing enhanced cooperation in the area of jurisdiction, applicable law and the recognition and enforcement of decisions in matters of matrimonial property regimes. Official Journal of the European Union. 2016. - L 183. - P. 1-29 (in English)

13. Dogovir mizh Ukrai'noju i Respublikoju Pol'shha pro pravovu dopomogu ta pravovi vidnosyny u cyvil'nyh i kryminal'nyh spravah vid 24 travnja 1993 roku [Agreement between Ukraine and the Republic of Poland on legal assistance and legal relations in civil and criminal matters from 24.05.1993] URL: https://zakon.rada.gov.ua/laws/show/616 174\#Text (in Ukrainian)

14. Davi A.L. Introduction in Calvo Caravaca, A.L., Davì, A., Mansel, H.P. (eds.), The EU Succession Regulation Commentary/ A.L. Davi. - Cambridge: Cambridge University Press, 2016. - P. 1-69 (in English)

15. Paulus D. Succession and Company Law in Bariatti, S., Viarengo, I., Villata, F.C. (coordinators), Towards the Entry into Force of the Succession Regulation: Building Future Uniformity upon Past Divergencies/ D. Paulus. - Milano: Università degli Studi di Milano, 2016. - P. 126-151(in English)

16. Odersky F. Article 4: Jurisdiction in Bergquist, U.; Damascelli, D.; Frimston, R.; Lagarde, P.; Odersky, F.; Reinhartz, B. EU Regulation on Succession and Wills Commentary/ F. Odersky. - Köln: Verlag Dr. Otto Schmidt KG, 2015. - P. 64-70 (in English)

17. Calvo Caravaca A.L. Article 21, General Rule in Calvo Caravaca, A.L., Davì, A., Mansel, H.P. (eds.), The EU Succession Regulation Commentary/ A.L. Calvo Caravaca. - Cambridge: Cambridge University Press, 2016. P. 298-322 (in English)

18. Lagarde P. Article 22: Choice of Law in Bergquist, U.; Damascelli, D.; Frimston, R.; Lagarde, P.; Odersky, F.; Reinhartz, B. EU Regulation on Succession and Wills Commentary/ P. Lagarde. - Köln: Verlag Dr. Otto Schmidt KG, 2015. - P. 125-130 (in English)

19. Lein E. Artikel 10 EuErb VO in Dutta, A., Weber, J. (eds.), Internationales Erbrecht: EuErbVO, Erbrechtliche Staatsverträge, EGBGB, IntErbRVG, IntErbStR, IntSchenkungsR/ E. Lein. - München: C.H. BECK, 2016. - S. 134-141 (in German)

20. Panopoulos G. Article 10-Subsidiary jurisdiction, in Pamboukis H.P. (ed.), EU Succession Regulation No 650/2012: A Commentary/ G. Panopoulos. - Athens, München, Oxford, Baden-Baden: Nomiki Bibliothiki, C.H. BECK, Hart Publishing, Nomos, 2017. - P. 145-153 (in English) 
21. European Commission. Proposal for a Council Regulation on jurisdiction, applicable law and the recognition and enforcement of decisions in matters of matrimonial property regimes COM/2016/0106 final - 2016/059, para 5.2. URL: https://eur-lex.europa.eu/legal content/en/ALL/?uri=CELEX\% 3A52016PC0106 (in English)

22. Pro mizhnarodni dogovory Ukrai'ny: Zakon Ukrai'ny vid 29 chervnja 2004 r. [Law of Ukraine on International Treaties of Ukraine from 29.06.2004] URL: https://zakon.rada.gov.ua/laws/show/1906-15\#Text (in Ukrainian)
23. Umowa między Rzeczpospolitą Polską a Ukrainą o pomocy prawnej i stosunkach prawnych w sprawach cywilnych i karnych sporzązona w Kijowie dnia 24 maja 1993 r. [Agreement between Ukraine and the Republic of Poland on legal assistance and legal relations in civil and criminal matters from 24.05.1993] URL: http://isap.sejm.gov.pl/isap.nsf/ DocDetails.xsp?id=WDU19940960465 (in Polish)

Received: $22 / 03 / 2021$

Accepted: $20 / 04 / 2021$

I. Dikovska, Dr of Law, Prof.

Taras Shevchenko National University of Kyiv, Kyiv, Ukraine

\section{SYNCHRONIZATION OF APPLICABLE LAW WITH FORUM IN SUCCESSION AND MATRIMONIAL PROPERTY MATTERS IN THE EU AND UKRAINE}

The purpose of this paper is to determine the ways of synchronization of applicable law with forum in succession and matrimonial property matters under the EU Succession Regulation and the EU Matrimonial Property Regulation and the rules which may determine international jurisdiction and applicable law in Ukraine as well as answer the question on whether the rules of the Law of Ukraine on Private International Law which ensure synchronization of applicable law with forum in succession and matrimonial property matters match the needs of legal regulation of private relationships.

The application of comparative, dialectical and formal-logical methods allowed concluding that synchronization of the applicable law with forum is provided by using of the same criteria for the determination of international jurisdiction and applicable law. The rules which ensure synchronization can: 1) necessarily lead to the application of the court's own law in some private legal matters; 2) be an alternative to the other methods of determination of the applicable law and international jurisdiction which is applied if the parties to the respective relationship conclude the choiceof-law and choice-of-court agreements linking to the law and the court of the same state.

Synchronization of the law with the forum in matrimonial property matters is possible under of the Law of Ukraine 'On Private International Law' if the spouses have concluded the choice-of-law and choice-of-court agreements and in some other cases.

It has been proved that the rules of the Law of Ukraine 'On Private International Law' which apply dualistic approach for determination of the law governing succession relationships does not allow to achieve synchronization of the applicable law with the forum in succession matters in all cases. It has been demonstrated that the presence of immovable property in the estate located abroad leads to the application of a foreign law to the succession of such property, even if a deceased, being a citizen of Ukraine, has chosen in his will the law of Ukraine as the law applicable to the succession. It has been concluded that the Law of Ukraine 'On Private International Law' should be amended in such a way that the choice of the law applicable to the succession made by a deceased in the will should cover the succession of movable and immovable property regardless of its location.

Keywords: synchronization of law with the forum; law applicable to succession; international jurisdiction in succession matters; international jurisdiction in family matters; Succession Regulation; Matrimonial Property Regulation; Agreement between Ukraine and the Republic of Poland on legal assistance and legal relations in civil and criminal matters; Law of Ukraine 'On Private International Law'.

Bulletin of Taras Shevchenko National University of Kyiv. Legal Studies, 2021; 2 (117): 24-29

УДК: 347.78

DOI: https:doi.org/10.17721/1728-2195/2021/2.117-5
ISSN 1728-2195

C) Taras Shevchenko National University of Kyiv,

Publishing center "Kyiv University", 2021

I. Ізарова, д-р юрид. наук, проф. ORCID ID: 0000-0002-1909-7020

Київський національний університет імені Тараса Шевченка, Київ, Україна

\section{МОДЕЛЬНІ ЄВРОПЕЙСЬКІ ПРАВИЛА ЦИВІЛЬНОГО ПРОЦЕСУ ЕLI-UNIDROІТ}

Здійснено загальний аналіз підготовлених у 2020 р. Модельних європейських правил цивільного процесу (далі - Правил), зокрема, охарактеризовано їхню структуру, визначено мету та завдання, основні принципи. Це дало можливість дійти висновків щодо ролі та значення вказаних Правил для подальшого розвитку цивільного процесу $i$ у державахчленах ЄC, і в інших державах, зокрема в Україні. Зазначено важливу роль уніфікації термінології цивільного процесуального права, яку було використано для підготовки Правил та яка в подальшому поширюватиметься завдяки широкому застосуванню в наукових дослідженнях, під час підготовки законодавчих актів тощо. Зокрема, ідеться про такі специфічні інститути цивільного процесуального права, як принцип співробітництва суду та сторін (cooperation between a judge and parties), принцип примирення (settlement), організація розеляду справи (саse management) та ін. Обгрунтовано, що визначена сфера дії й основні принципи Правил зумовлюють необхідність переосмислення традиційних підходів до регулювання відносин, що пов'язують сторони й їхніх представників, а також суд під час розеляду справи, нові підходи до стадійності розеляду справи судом і диференціації цивільного судочинства.

Ключові слова: доступ до правосуддя; цивільне судочинство; принцип урегулювання спорів; принцип співробітництва суду та сторін; принцип пропорційності; ефективний захист прав.

ВСТУП. Доступне правосуддя для всіх стало невід'ємним елементом сучасної парадигми верховенства права та супроводжує будь-які реформи на шляху розбудови демократичної правової держави. Забезпечення рівного доступу до правосуддя для всіх визначено однією із цілей сталого розвитку $[1 ; 2]$, що обумовлює підвищення інтересу до ефективних шляхів його досягнення, зокрема й до досвіду провідних держав світу, розвитку їхньої правової доктрини та практики її застосування.

У сфері цивільного процесу та судоустрою за останні десятиліття процеси гармонізації і зближення здійснили настільки вагомий вплив, що ці сфери, які ще вчора вважалися найконсервативнішими, отримали істотний поштовх до свого розвитку з метою забезпечення рівного доступу всіх до правосуддя. Зокрема, ідеться про здобутки величезного проєкту, який здійснено зусиллями провідних науковців і двох установ ЄС - Європейського інституту права (European Law Institute або ELI) та Міжнародного інституту уніфрікації приватного права (International Institute for the Unification of Private Law aбo Unidroit) [3; 4].

Упродовж кількох років, коли здійснювалася підготовка зазначених Правил, з'явилися кілька наукових публікацій, що проливали світло на внутрішню роботу Робочих груп із підготовки їхніх окремих частин [5-9]. Деякі 3 них були перекладені українською мовою й доступні для ширшого загалу [10-12]. Водночас, багато питань щодо цілей і структури Правил можна дос- 